\title{
The Influence of Organisational Culture on Mainstreaming Monitoring and Evaluation in Public Entities Revenue Services
}

\section{K. Sebedi}

Cultural forces are powerful because they operate outside of our awareness. We need to understand them not only because of their power but also because they help to explain many of our puzzling and frustrating experiences in social and organizational life. (Edgar Schein, 2010).

\section{Abstract}

Desearch informs us that most of the Rproblems confronting governments can be traced to their inability and failure to appropriately analyze and evaluate organizational culture. This article argues that there is a direct link between organizational culture, organizational performance, as well as monitoring and evaluation. Understanding the effect that organizational culture has, is a significant factor of good governance. The importance of a strong organizational culture together with effective monitoring and evaluation processes contribute appreciably towards efficient performance and effective service delivery. Yet, mainstreaming monitoring and evaluation in government departments and entities is often met with varying challenges. Such challenges can be better understood and addressed through aligning the entities' organizational culture to government's monitoring and evaluation initiatives. The focus of the article is on responding to the pertinent question: what are the current challenges relative to implementation and how should they be addressed? The article will thus highlight some of the key challenges that are associated with organizational culture, which have direct impact on the mainstreaming of monitoring and evaluation.

Keywords: Organisational Culture, Efficient Performance, Revenue Service, Monitoring and Evaluation, Ethics, South Africa. 


\section{Introduction and Background}

Scholars such as Hoffman (1986) and Weiss (1986) argue that studies on organizational culture were quick to promote the idea that "organizational culture had a great potential as a means of improving ethics in the organization." They suggest that ethics and culture began to be confused the moment they share a reference to certain common values in an organization - values which supposedly embody the basic shared beliefs about the nature of the organization and its employees' significance in rendering service to clients. The possibility of approaching organizational culture from an ethical angle arises when these cultures have been verified, and thoughts and actions of individuals in the organization are culturally influenced, that individuals can act and operate according to different standards and criteria depending on the context. Socialization processes in organizations are usually aimed at shaping individuals to fit into a normative structure. This article seeks to study the link between organizational culture and ethical values in the South African Revenue Services (SARS), and how they are being operationalized in the service delivery value chain.

The assessment of something as complex and amorphous as an organization's culture has been the subject of much debate. Some argue that each culture is unique and must be intuitively "sensed" rather than measured; others argue that the best way to uncover culture is through ethnographic studies that analyze the stories and accounts of events making up the folklore of every organization (Denison, 1984:6). This article attempts to assess the link between organizational culture, ethics and how they affect service orientation in the South African Revenue Services (SARS) as variables of service delivery. Changes in South Africa prior to the 1994 democratic elections have affected the ways in which the government departments, parastatals, public finance sector and the private sector conduct their business. According to Davidson (2003:1) the old methods of acquiring and developing business have been changed and new models for leadership and management have been called for. Such changes require the public financial sector leadership and management to be far more knowledgeable about their business area, global challenges and be more competitive on how they approach such areas. The quality of services rendered is the key factor for sound financial management, attracting and retaining customers, human resources, corporate governance, and organizational development. All these factors are vital elements of total quality management (TQM).

In South Africa, according to the White Paper on the Transformation of the Public Service (also referred to as the Batho Pele White Paper 7 ), 2003 (par, 2 on Principles) the service standards must specify the level quality and quantity of service to be rendered and, must cover processes and outcomes. In this sense, service standards must be set at a demanding but realistic level to be reached by adopting more efficient and customer focused working practices. The Batho Pele White Paper, 2003, stipulates that the

\footnotetext{
7Batho Pele is a Sesotho phrase that means "People first."
} 
expected target per employee according to Client Service business area in the organization to be researched is 480 minutes per day multiplied by a number of twenty working days to reach $100 \%$ target per month.

In line with the Batho Pele principles, the study was influenced and motivated by the literature of economists, organization theorists, management philosophers, financial analysts, management scientists and consultants on organizational effectiveness, productivity, efficiency or excellence and has served as a unifying theme for many years of research on the management and design of organizations. However, Lewin and Minton (1986: 514) caution that empirical research has not contributed to the development of a universal theory of organizational effectiveness and measures of effective service in the past, but has often been based on a set of subjective measures. This study therefore seeks to add to the scholarship of organizational effectiveness, using one public finance institution, that is, the South African Revenue Services (SARS), to illuminate the extent to which organizational effectiveness contributes to ethical values and improved customer service. This article is aimed at presenting results of an assessment of how SARS is progressing in the implementation of principles of organizational culture, performance, governance, monitoring and evaluation.

Organizations have restructured, re-engineered, merged, benchmarked, implemented total quality management programs and introduced competitive employee benefits with the aim of achieving desired levels of service or organizational performance. To date, organizations are still not achieving the expected results and ask themselves why they are not achieving high performance despite these attempts (Jeuchter, Fisher and Alford, 1998: 63).

\section{Research Approach}

This article presents a culture model that shows a direct link between culture, ethical values, performance, and monitoring and evaluation; and in the long term elevates the importance of the concept of organizational culture in the South African business environment. Van der Post, de Koning and Smith (1998:30) point that literature has been conducted on the relationship between organizational culture, ethics and service orientation but there is not much statistical evidence supporting this relationship. It is from this point of view that this article was set out to answer the question: Is there a direct relationship between organizational culture, ethics and service orientation in the South African Revenue Service (SARS)? If yes, to what extent does this relationship contribute towards accelerated service delivery in SARS?

The specific objectives of this article are to conceptualize culture within the Public Finance Sector as a service sector (using SARS as an agency of the state) and to determine its key aspects; determine how culture in this specific environment can be measured; determine the influence or correlation between culture, ethics and service orientation; show the importance of culture within an organization; and determine what service orientation is and how does it relate to organizational performance. 
Lytle, Hom, and Mokwa (1998) developed an instrument, "the SERV*OR scale" to measure organizational service orientation. This instrument has been used extensively in banks in the United States of America. These developers further stress that a thorough rigorous methodological process has proven that $S E R V^{*} O R$ is an instrument that is not only reliable but also has been validated. The scale has proven to be robust and psychometrically sound as it has undergone multiple rounds of pre-testing and testing across multiple employees and different organizations and different work environments in industries as well, for service orientation diagnosing in the United States of America Lytle, Hom, and Mokwa, (1998). In this research article, while the SERV*OR scale is acknowledged, a slightly different instrument which is customized to the South African environment is used. The measurement instrument to be used is the High Performance Culture Questionnaire (HPCQ v1.2).

The study adopted a combination of the quantitative and qualitative research methods. A questionnaire was used as the primary data collection instrument. The questionnaire covered aspects of both culture and service orientation. An existing questionnaire, that is, the High-performance climate (culture) HPCQ 1.2 questionnaire was used for the measurement of the independent variables, that is, organizational culture, ethics and service orientation. This instrument was validated in the same population by Gerber in 2010.

\section{Theoretical Framework}

While it has been claimed that culture accounts for the economic performance of various countries, the idea of corporate culture serves to provide basis for understanding the difference that may exist between successful companies operating in the same national culture (Hofstede \& Bond, 1998:4). Ouchi (1981:24) presents a similar relationship between corporate culture and increased productivity. In addition, a number of authors (Deal and Kennedy, 1982; Lim, 1995; Denison and Mishra, 1995; Davidson, 2003) argue that the importance of a strong culture is contributing towards successful financial performance and service orientation. A few studies appear to have actually examined the existence and the nature of this relationship or presented supporting evidence for it. In this article, we argue that there is a link between culture and organizational performance. Organizational performance is highly influenced by the prevailing organizational culture.

From an international perspective, some American organizations have attributed their success to the specific culture of each of their respective organizations (Ouchi, 1981; Deal and Kennedy, 1982; Peters and Waterman; 1982; Lewis, 1994). Culture has some effects on the organization's ability to function as it sets boundaries within the organization. In order to achieve sustainable performance, organizations' culture and people must be fully prepared and aligned to support that change initiatives that are 
brought up regularly. According to Jeuchter, et al., (1998:63) culture is what distinguishes truly high-performance organizations from the rest of the pack.

Studies on organizational culture in the Western organizations in the late 1920s conducted by Hawthorne in an attempt to understand the importance of the culture of a work group found that culture has a greater impact on productivity than technology or working conditions (Schuster, 1986:30). Although the study was done in the 1920s, its results are still relevant to date. According to Davidson (2003:2) Hawthorne's study is directly relevant in today's efforts to understand and manage corporate or organizational culture.

Ouchi (1981:24) refers to the world's pragmatic interest in how Japan, as an industrial society, has achieved its outstanding and envied economic success has led to a high incidence of literature and research papers based on comparative studies of the cultures in Japanese and Western organizations, and how these cultures impact on productivity. Japan is currently one of the leading countries with high productivity rate. South Africa can also learn from Japan's successes and follow on its steps, more especially on its quest for sustainable development.

Kotter and Heskett, (1992:25) have established that corporate culture has a significant effect on an organization's long term sustainability and economic performance. They found that, over an 11 year period organizations with an embedded culture had greater revenue increases in the share price and larger improvements in net income than their counterparts with not so strong cultures. Tidball (1988:63) highlights the importance of establishing linkages between the elements of organizational culture and outcomes such as profitability, turnover and commitment. She indicates that congruence of beliefs seems to create a unifying force that boosts organizational performance and service orientation. When people can clearly see the link between their behaviour and the profitability of the organization, those behaviours will tend to be reinforced. This article concurs with Tidball's thesis in this regard.

The results of Tidball's study indicate that culture is a force that affects both employee behaviour and the success of a company. A later study by Denison (1990:15) has also found clear compelling relationship between an organization's culture and the bottom-line business performance through service, that is, service orientation. Again, Kotter and Heskett (1992:52) are of the opinion that corporate culture is however, something that is not static and, although difficult to change, can be made more performance enhancing. It is from this perspective that this article acknowledges organizational culture and service orientation as a contributing factor in service delivery.

\section{Conceptual Definitions of Organizational Culture and Service Orientation}

According to Schein (1990), most of the problems confronting leaders can be traced to their inability to analyse and evaluate organisational culture. Lincoln (2004:5) is of the view that culture is arguably the most pervasive buzzword in the popular management lexicon, routinely invoked in business discourse to sum up all that is distinctive in a company. Defining organisational culture is, however, not an easy task. While there is a 
general agreement about the components of culture as a broad construct, there is considerable disagreement about:

- what constitutes organisational culture;

- whether the culture of a given organisation can ever be adequately described;

- whether culture management can ever be truly effective and, if so;

- which management strategies are most likely to succeed (Willcoxson \& Millett, 2000).

The BusinessDictionary.Com (2010) defines Organizational culture as the total of an organization's past and current assumptions, experiences, philosophy and values that hold together, and are expressed in its self-image, inner workings, interactions with the outside world, and future expectations. Denison and Mishra (1995) define organizational culture as providing the underlying values, beliefs and principles that serve as a foundation for an organization's management system, as well as the set of management practices and behaviours that both exemplify and reinforce those basic principles. Schein (1992) defines organizational culture as the pattern of shared basic assumptions invented, discovered, or developed by a given group as it learns to cope with its problems of external adaptation and internal integration that has worked well enough to be considered valid and, therefore, to be taught to new members as the correct way to perceive, think, and feel in relation to those problems. Similarly, AimanSmith (2004) posits that organizational culture is commonly held in the mind framework of organizational members. The framework contains basic assumptions and values. These basic assumptions and values are taught to new members as the way to perceive, think, feel, behave, and expect others to behave in the organization.

ESPO (2002:13) perceives culture as a metaphor by which one strives to understand a company's operations and ways of reacting to environmental pressures. It is from this perspective that McNamara (2007) defines organizational culture as the personality of the organization. In this sense, the organization is personified. Therefore, culture is seen as comprising of the assumptions, values, norms and tangible signs (artefacts) of organization members and their behaviours. According to Davies, Mannion, Powell and Marshall (2007) organizational culture denotes a wide range of social phenomena, including an organization's customary dress, language, behaviour, beliefs, values, assumptions, symbols of status and authority, myths, ceremonies and rituals, and modes of deference and subversion; all of which help to define an organization's character and norms. Unsurprisingly, in view of this diverse array of phenomena, little agreement exists over a precise definition of organizational culture, how it should be observed or measured, or how different methodologies can be used to inform routine administration or organizational change. From the entrepreneurial perspective, McGuire (2003) adds creativity and tolerance of creative people in the organizational culture. From the above definitions, it can be deduced that an organization is viewed as a living being when 
defining the culture that prevails in the behavioural patterns of people that are associated with that organization.

As is the case with organizational culture, defining what service orientation is, is equally not so easy. The Dictionary of Dimensions (2010) defines service orientation as listening to and understanding the customer (both inside and outside government); anticipating customer needs; giving high priority to customer satisfaction. To most citizens, the contact person is the organization. In their eyes, the organization is only as competent, knowledgeable, courteous, and reliable as the person who represents it.

In this research article, "service orientation" is defined as a set of organizational policies, practices, and procedures intended to foster the creation and delivery of service excellence. Service-Orientation depicts the delivery of any valued output via a service from one party to another. It is based on the theory of the marketplace. Lytle, Hom, and Mokwa (1998), are of the view that the service orientation of an organization is what the employees perceive it to be. As such, any service orientation can best be understood through considering employee's perceptions, beliefs, and opinions.

From an organizational standpoint, service can only be rendered if the organization (servers/employees) exists at appropriate points in the creation and delivery chain and is capable (willing and able) of attending to customer needs (Berry, Parasuraman and Zeithaml, 1994). The concept of leading by doing then becomes relevant. The behaviour and leadership style of management should be visible in leading by doing (Berry, et al., 1994; Heskett, Sasser and Schlesinger 1997). Management should be actively involved in helping, assisting and meeting the needs of employees within the work place. They should inspire, motivate and mentor employees in achieving the expected organizational service excellence. From this assertion, it is worth mentioning that organizational service orientation is prevalent where the organizational climate is seen to be nurturing and rewarding service practices and behaviour known to meet customer expectations (Lynn, Lytle, and Bobek (2000).

Many service organizations have recently made the shift from activity orientation to process orientation. The functionality offered by the organization is viewed from within the organization which focuses on employees, resources, policies, practices, and procedures intended to foster the creation and delivery of service excellence. The service excellence is as a result of monitoring and evaluation which has been operationalized and managed, and Monitoring involves collecting, analyzing, and reporting data on inputs, activities, outputs, outcomes and impacts as well as external factors, in a way that supports effective management, while Evaluation may assess relevance, efficiency, effectiveness, impact and sustainability (www.thepresidency.dpme.gov.za) Yoon, Choi and Park (2007). Service orientation is of relevance in a democratic state such as the Republic of South Africa. The public, to whom services are rendered need to be served in a standard that satisfy their interests. They have the right to demand explanations in cases where the service rendered is not at the expected standard. 


\section{Culture and Service Orientation - two sides of a coin}

Scholars such as Deshpande and Webster (1989) and Schein (1985) suggest that organizational functioning cannot be adequately understood by myopically examining traditional models or organizational behaviour that generally incorporates organizational task, structure and people but not culture. They argue that organizational culture can impact and even determine organizational behaviour and its effectiveness among competitors. This view is supported by Webster (1993), Ouchi and Wilkins (1985), and Peters and Waterman (1982). Service orientation stays in the strong site with intangible aspects of an organization, that is, what makes the organization excel. Lynn, Lytle, and Bobek (2000) are of the opinion that service orientation exists when the organizational climate for service crafts, nurtures and rewards service practices and behaviours meet customer needs.

Gonzalez and Garazo (2006) further identified three main variables related to organizational citizenship behaviour as a result of the positive influence on employees' satisfaction namely:

a) Whether employees act as representatives of the firm to outsiders;

b) Contact-staff participation consists in providing information about customer needs and suggesting improvements in-service delivery process; and

c) Following company regulations in such conscientious manner that they are adapted to the individual customer needs.

Organizational citizenship briefly refers to "go the extra mile" to offer customer service. This relates to the sense of ownership of the task, responsibility and accountability, and utilization of the organizational resources to provide excellent service. This is how things are done around here. It is what the organization focuses on or directs its efforts to in rendering service. It becomes the culture of the organization to encourage and promote the sense of belonging and team membership (Robbins 2005; Schneider, Macey, and Young 2006). This definition captures one of the basic challenges faced by any culture to reconcile the often divergent aims and actions of its members. It also points to the difficulty of addressing that challenge. Its emphasis on the role of shared basic assumptions influencing beliefs and behaviour suggests that organizational culture denotes much more than the definition Schein (1990). Schein is also of the opinion that changing the way things are done appears, on the functional level of systems redesign, relatively easy.

Business performance characteristics such as employee satisfaction, service value and customer may have an impact on service orientation and that shows that service orientation is related to business performance as it is the manner in which service is rendered to customers (Yoon, Choi, and Park, 2007). Organizational service orientation is being described in the context of service organization climate (Lytle and Timmerman, 2006; Lynn, Lytle, and Bobek, 2000; Lytle, Hom, and Mokwa, 1998). All the authors agree that climate and culture are interconnected. Employees' values and beliefs which are 
part of culture, influences their interpretation of organizational policies, practices and procedures which is climate (Schneider, Brief, and Guzzo, 1996). They are of the opinion that organizational climate includes employees perceptions of the policies, practices and procedures that are rewarded, supported and meeting the said standard of service to clients (Schneider, Salvaggio, and Subirats, 2002). Despite the positive role played by service orientation in an organization, there are also exceptions. Henning-Thurau and Thurau (2003) are of the view that service orientation has three dimensional constructs focused on employees namely: their motivation to serve customers; their skills; and their self-perceived decision-making authority. It is considered that service orientation and organizational culture are part of a wider concept of the organization's overall climate. Organizational culture and ethics are being introduced, as they form core nature of SARS business in providing service.

Government's major challenge is to become more effective, and Monitoring and Evaluation (M\&E) processes can assist the public sector in evaluating its performance and identifying the factors which contribute to its service delivery outcomes. M\&E is uniquely oriented towards providing its users with the ability to draw causal connections between the choice of policy priorities, the resourcing of those policy objectives, the programmes designed to implement them, the services actually delivered and their ultimate impact on communities. It is against this background that SARS as an organisation has aligned its policies, programmes, and strategic objectives with the Constitutional Mandate, and Government Policy objectives of rendering effective and excellent service to the public. M\&E should be skilfully undertaken ethically and with integrity, and carries the element of accountability. These formal managerial elements are the organizational culture, capacity and other enabling conditions which will determine whether the feedback from the M\&E function influence the organization's decision-making, learning and service delivery (www.thepresidency.dpme.gov.za).

\section{Organizational Culture and Ethics (Governance)}

The organization understudy's key ethical values are:
a) Mutual respect and Trust
b) Integrity and Honesty
c) Transparency and Openness and
d) Courtesy and Commitment

It is therefore necessary to also incorporate (Schein, 1985) dynamic vision which looks at the processes that compromise organizational culture, so that the discourse on corporate values legitimated by this approach is not reduced to perspective that is merely analytical or instrumental. Schein's approach provides us with several instruments which enable us to focus more closely on ethics, as he defines organizational culture. Schein (2010) focuses on leadership as the key factor in understanding and influencing corporate dynamics. It is here when we can begin to link organizational culture with ethical thought as part of the organizational process which 
includes leadership, it is where talking about corporate culture involves talking about a group, a content (values), borders (shared), and a relationship between them, training process that transmits this culture (Bourcier,1988).

Robbins and Judge (2009) suggest the following list of management practices that can be done to create a more ethical organizational culture:

a) Be a role model and be visible: Employees look to the behaviour of top management as a model of what is acceptable behaviour in the workplace. If senior management is observed to take the ethical high road, it sends a positive message for all employees

b) Communicate ethical expectations: Ethical ambiguities can be reduced by creating and disseminating an organizational code of ethics. It should state the organization's primary values and ethical rules that employees are expected to follow. It should be noted however that a code of conduct is worthless if top management fails to model ethical behaviours.

c) Offer ethics training: Seminars, workshops and similar ethical training programs. These training sessions should be used to reinforce organization's standards of conduct, to clarify what practices are permissible and unacceptable, and to address ethical dilemmas.

d) Visibly reward ethical acts and punish unethical ones: Performance appraisals of management should include a point-by-point evaluation of how decisions measure up against the organization's code of ethics. Appraisals must include the means taken to achieve goals as well as the ends themselves. People who act ethically should be visibly rewarded for their behaviour. Just as importantly, unethical acts should be punished.

e) Provide protective mechanisms: The organization needs to provide formal mechanisms so that employees can discuss ethical dilemmas and report unethical behaviour without fear of reprimand. This might include creation of ethical counsellors, ombudsmen, or ethical officers.

Sims and Brinkmann (2003) describe the case of Enron as an example of unethical organizational culture, where there was contradiction between words and deeds. Enron executives created an organizational culture that valued profits over ethical behaviour. SARS as an organization is vocal and visible in its attempt to stamp out corruption and unethical behaviour internally and externally. It stands out as a leading organization in Public Administration where anti-corruption mechanisms have been operationalized, and form part of the organizational culture and service orientation. It is imperative to look at the level at which employees commit to these values as they form part of the organizational culture. 


\section{Organizational Values and Commitment}

Robbins (2001) suggests that effective management-employee communication leads to employee motivation and commitment. This view is being shared by Stuart (1999) who further argues that communication can affect empowerment of employees and lead to employees' organizational commitment. Organizational commitment as an act has been defined as a strength of an individual's identification with a particular organization (Mowday et al., 1979; Allan and Meyer, 1990). Meyer et al., (2002) support this definition by reflecting an individual's affective commitment to these values represents a major approach to the study of organizational commitment. Ghani et al., (2004) state that employees with strong organizational commitment choose to continue working for the organization. Organization's leadership need to support their employees' value by involving them in the organization, and make them have a sense of belonging as essential part of the organization.

Ethical behaviours are vital to an organization's overall success. A well-documented and detailed Business Code of Conduct is an employee's essential tool that can be used in case of ethical dilemma. If an organization chooses to engage on employee monitoring, the practice should be communicated to all employees and be in line with organizational policies, business code of practice, and laws of the country. Hartman (2001) further suggests that organizations need to be careful and consistent when they are monitoring employee's use of electronic equipment, and respect their right to privacy.

Schein (2010) further suggests that as one observes an organization, there are some assumptions that characterize the whole organization, called corporate culture, and a set of assumptions that characterize subunits of the organization. These subcultures reflect the fundamental units, the rank levels in the hierarchy, isolated geographic units, and other groups that have shared history. All organizations operate within three generic subcultures that reflect the operations of the organization, the design of the organization, the Executive/Financial function of the organization. Schein emphasizes that for the organization to be effective these subcultures must be in alignment with each other because each is needed for total organizational effectiveness. Salted and van de Putte (2004) emphasize that effective service requires integration of monitoring and evaluation and learning systems at different levels in the organisation. Such integration requires a clear vision with regard to organizational learning and the practical development of monitoring and evaluation. Within this context, attention needs to be paid to the organizational culture and structure, as well as to monitoring and evaluation systems, their linkage to work processes and the necessary staff competencies.

Now that the concepts of organizational culture, ethics (governance), monitoring and evaluation, and organizational values have been defined and discussed, it is imperative to present the results of the questionnaires administered at SARS to assess the extent to which organizational culture and service orientation contribute towards improving service delivery. 


\section{Presentation of Results and Discussion}

Perception rating was chosen as a measurement of service orientation in the sample of 300 employees for practical application. Authorization to administer organizational culture measurement instrument "the High Performance Culture Questionnaire (HPCQ v1.2)" which was used in the South African Revenue Services, using the same population sample and, validated by Gerber in 2005 and later modified in 2010 was obtained. It should be noted that the High Performance Culture Questionnaire HPCQ (v1.2) does not measure the values and beliefs, but it is focused on the practices within the organization, it is more universal, and it has the potential for use in specific cultures and variety of organizations including Public Administration. But, because it is a lengthy instrument and may impact negatively on operational time to administer, a decision was taken to obtain a perception rating of service orientation in the identified sample. In the below paragraphs, a highlight of the validity and reliability of the HPCQ v1.2 is discussed. The results of the questionnaire administered in the organization under study are thus presented below:

$\begin{array}{ll}\text { 1) Client service orientation } & 0,868 \\ \text { 2) Goals and objectives } & 0,853 \\ \text { 3) Vision } & 0,878 \\ \text { 4) Values } & 0,944 \\ \text { 5) Diversity } & 0,784 \\ \text { 6) Managerial leadership } & 0,870 \\ \text { 7) Quality emphasis } & 0,880 \\ \text { 8) Empowerment } & 0,869 \\ \text { 9) Employee training } & 0,877 \\ \text { 10) Teamwork } & 0,852 \\ \text { 11) Individual importance } & 0,815 \\ \text { 12) Overall satisfaction } & 0,796 \\ \text { 13) Employee retention } & 0,745 \\ \text { Total questionnaire } & \mathbf{0 , 9 6 7}\end{array}$

The results indicate that, in terms of service orientation, organizational values are highly rated with the score of 0.944 . Employee empowerment and training have also received significant consideration with 0.869 and 0.877 respectively. However, in terms of the overall satisfaction, SARS does not do well, with a score of 0.796 . The overall satisfaction confirms the rating of the individual importance of service orientation as it has scored a high rating of 0.815 .

From the above responses, this article argues that there is a need for SARS to focus its attention on addressing the satisfaction levels of its employees. Employee satisfaction is seen as a contributing factor to the overall performance of the organization. At this point, it can be safely said that, the results of the questionnaire confirms the hypothesis of this research which are: 
(a) The demographic variables of gender managerial level, length of service and race influence service orientation;

(b) The demographic variables of gender managerial level, length of service and race influence organizational culture; and

(c) The organization's culture influences the level of client service orientation of employees.

The research findings in the organization understudy, SARS, do not only show the correlation between culture, values and service orientation but also an impact of culture on organizational performance and quality of service. The findings revealed that the role of strong leadership behaviour and promotion of organizational values should be emphasized in achieving excellent service quality through giving support to employees to enable them to achieve organizational goals and objectives.

Based on the results of this study, this article concludes that the adoption of a service orientation strategy that incorporates ethical values will lead to improved service quality and improved employee satisfaction. Of the two dimensions measured, culture, values, and service orientation, customer or client service focus is the more powerful in terms of explaining variations in the service quality dimension of tangibles, reliability, assurance, responsiveness and empathy.

\section{Conclusion}

This article has argued that organizational service orientation affects service performance and its influence on service quality and client loyalty. Service orientation might be used in a management process as a concept for service organization assessment. Moreover, orientation also provides a framework to service organization improvement. The impact of organizational culture on ethics, service orientation, organizational performance and quality of service in SARS is visible. In conclusion a strong leadership behaviour and promotion of organizational values are important for excellent service quality and support for employees to obtain the required quality of service (Albrecht and Zemke 1985, Heskett, Sasser, and Schlesinger 1997). The practice of monitoring and evaluating has made great progress in the past decade. Evaluation nowadays not only takes place in the Bank's work but also around the world in governments assessing how in the longer term organizations are performing and government expenditures impact the population (http://go.worldbank.org/SMB4XVCIHO). The bottom line for leaders is that if they do not become conscious of the cultures in which they are embedded, those cultures will manage them. Culture understanding is essential for all, but it is essential to leaders if they are to lead. Schein (2010). 


\section{List of References}

- Aimen-Smith, L. 2004. What do we know about Developing and Sustaining a Culture of Innovation? The Journal of Marketing, 57, 23-27.

- Albrecht, K. \& Zemke, R. 1985. Service America! Doing business in the service economy. Dow Jones-Irwin, Homewood, IL.

- Allan, N. J., \& Meyer, J.P. 1990. The measurement and antecedents of effective, continuance and normative commitment to the organization. Journal of Occupational Psychology, 63, 1-18.

- Berry, L.L., Parasuraman, A., \& Zeithaml, V.A. 1994. Improving service quality in America: lessons learned, developing the Service Orientation for Spiritual Capital. Leadership Capacity for executive, 8(2), 32-52.

- Davidson, G.M. 2003. The Relationship between Organizational Culture and Financial Performance in a South African Investment Bank. Unpublished Masters of Commerce Manuscript: University of South Africa.

- Davies, H.T.O., Mannion, R., Jacobs, R., Powell, A.E., \& Marshall, M.N. 2007. Exploring relationship between senior management team culture and hospital performance. Medical Care Research and Review, 64(1), 46-65.

- Davis, S. (1984). Managing Corporate Cultures. Cambridge, M.A: Ballinger.

- Deal, T.E. \& Kennedy, A.A. (1982). Corporate Cultures: the rites and rituals of corporate life. Reading, M.A: Addison-Wesley.

- Denison, D.R. 1984. Bringing culture to the bottom line. www.q3.ca/articles/archives/articles/2006_04/Denison_bringing_culture. Accessed 28/05/2010.

- Denison, D.R., \& Mishra, A.K. 1995. Towards a Theory of Organizational Culture and Effectiveness. Organization Science, 6(2), 204-223.

- Deshpande, R., \& Webster, F.E. Jr. 1989. Organizational Culture and Marketing: Defining the Research Agenda. Journal of Marketing 53 (1), 3-15.

- ESPO. 2002. VTT research notes 2140. ESPO.

- Gerber, F.J. 2009. Guide to the High-Performance Climate Questionnaire HPCQ (v1.2), (unpublished). 
- Ghandi, R.A., Nordin, F., \& Mamat, L. 2004. Organizational commitment among the academic staff in the Distance Education Program. The International Journal of Education development, 1, 29-43.

- Gonzalez, J.V. \& Garazo, T.G. 2006. Structural relationships between organizational service orientation, contract employee job satisfaction and citizen behaviour. International Journal of Service Industry Management, 17(1), 23-50.

- Hartman, L. 2001. Perspectives In Business Ethics. Chicago: Irwin/ McGraw-Hill.

- Henning-Thurau, T. \& Thurau, C.U. 2003. Customer orientation of service employees: towards a conceptual framework of a key relationship marketing construct. Journal of Marketing, 21(1/2), 23-41.

- Heskett, J.L., Sasser, W.E. Jr., \& Schlesinger, L.A. 1997. The service profit chain: How leading companies link profit and growth to loyalty, satisfaction, and value. New York: The Free Press.

- Hoffman, W. M. 1986. What is Necessary for Corporate Moral Excellence? in Journal of Business Ethics, 5 (1986),p. 233-242.

- Hofstede, G. \& Bond, M.H. 1988. The Confucius connection: from cultural roots to economic growth. Organizational Dynamics, 16(4), 4-21.

- Jeuchter, W.M. \& Fisher, C. \& Alford, R.J. 1998. Five conditions for high performance cultures. Training and Development, 52(5), 63-67.

- Lewin, A.Y \& Minton, J.W. 1986. Determining organizational effectiveness: another reactions, behaviour and organizational performance. Journal of Organizational Change, 7(5), 41-55.

- Lewis, D.S. 1994. Organizational change relationship between reactions, behaviour and organizational performance. Journal of Organizational Change, 7(5), 41-55.

- Lim, B. 1995. Examining the organizational culture and organizational performance link. Leadership and Organizational Development Journal, 23(2), 3547.

- Lincoln, J.R.M., Hananda , M \& Olson, J. 2004. Cultural orientation and individual reactions to organizations: A study of employees of Japanese owned firms. Administrative Science Quarterly, 26(4), 93-115.

- Lynn, M.L, Lytle, R.S, \& Bobek, S. 2000. Service orientation in transitional markets: does it matter? European Journal of Marketing, 34(3/4), 279-298.

- Lytle, R.S., Hom, P.W., Mokwa, M.P. 1998, "SERV*OR: a managerial measure of organizational service-orientation". Journal of Retailing, 74(4), 455-489. 
- Lytle, R.S, \& Timmerman, J.E. 2006. Service orientation in transition and performance: an organizational perspective. Journal of Service Marketing, 20(2), 136-147.

- McGuire, S.J.J. 2003. Entrepreneurial organizational culture: construct definition and instrument development and validation. (Unpublished PhD Dissertation). The George Washington University, Washington, DC.

- McNamara, C. 2007. Organizational culture: field guide to leadership and supervision, http://www.managementhelp.org_thry/culture/culture.htm. Accessed 12/06/2007.

- Meyer, J.P., Stanley, D.J., Herscovitch, L., \& Topolaytsky, L. 2002. Effective, continuance, and normative commitment to the organization: Ameta-analysis of antecedents, correlates, and consequences. Journal of Vocational behaviour, 61, 20-52.

- Monitoring and Evaluation, http://go.worldbank.org/SMB4XVCIHO Accessed $26 / 09 / 2012$

- Mowday, R.T., Porter, L.W., \& Stress, R.M. 1979. The measures of organizational commitment. Journal of Vocational Behaviour,22 (8), 90-6.

- Ouchi, W.G. (1981). Theory of Z: how American Business can meet the Japanese Challenge. Reading MA: Adison-Wesley Publishing Co.

- Ouchi, W.G., \& Wilkins, A.L. 1995. Organizational culture. Annual Review of Sociology, 11, 457-483.

- Peters, T.J. \& Waterman, R.H. 1982. In search of excellence. New York: Harper and Row.

- Policy Framework for the Government -wide Monitoring and Evaluation, (www.thepresidency.dpme.gov.za).

- Robbins, S. (Ed.). 2001. Organizational behaviour: Concepts, controversies, applications. Engelwood Cliffs, NJ: Prentice-Hall

- Robbins, S. 2005. Organizational behaviour. 10 $0^{\text {th }}$ Edition. Englewood Cliffs, NJ: Pearson Education.

- Robbins, S.P., \& Judge, T.A 2009. Organizational behaviour $13^{\text {th }}$ Edition. Upper Saddle River, NJ: Pearson Education, Inc.

- Salted and van de Putte, 2004. Linking monitoring \& evaluation to Organizational learning 11-15 October 2004 www.mande.co.uk Accessed 26/09/2012

- Schein, E. H. 1985. Organizational Culture and Leadership, London, Jossey-Bass. 
- Schein, E.H. 1990. Organizational culture. American Psychologist, 45(2), 109-119.

- Schein, E.H. 1995. The role of the founder in creating organizational culture. Family Business Review, 8(3), 221-238.

- Schein, E. H. 2004. Organizational culture and leadership. $3^{\text {rd }}$ Edition. San Francisco: Jossey-Bass.

- Schein, E. H. 2010. Organizational culture and leadership. $4^{\text {rd }}$ Edition. San Francisco: Jossey-Bass.

- Schneider, B., Salvaggio, A., \& Subirats, M. 2002. Climate strength: a new direction for climate research. Journal of Applied Psychology, 87, 220-229

- Schneider, B., Brief, A.P., \& Guzzo, R.A. 1996. Creating a Climate and Culture for Sustainable Organizational Change, Organizational Dynamics, 24(4), 7-19.

- Schneider, B., Macey, W.H., Young, S.A. 2006. The climate for service: review of the construct with implications for achieving CLV goals, Journal of Relationship Marketing, 5 (2/3), 111-32.

- Schuster, F.E. 1986. The Shuster report: the proven connection between people and profits. New York: John Wiley.

- Sims, R.R., \& Brinkmann, J. 2003. Enron ethics (or: Culture matters more than codes). Journal of Business Ethics, 45(3), 243-256.

- South Africa (Republic). 1995. White Paper on the Transformation of the Public Service. Pretoria: Government Printer.

- Stuart, H. 1999. Towards a definitive model of the corporate identity management process. Corporate Communication, 4(4), 200-207.

- The BusinessDictionary.Com. 2010. http://www.businessdictionary.com/definition/organizational-culture.html. Accessed 29/05/2010.

- The Dictionary of Dimension. 2010. http://www.uncg.edu/hrs/serorien.htm. Accessed 29/05/2010.

- Tidball, K.H. 1988. Creating a culture that builds your bottom line. The Cornell H.R.A. Quarterly, 29(1), 63-69.

- Trevino, L. K. 1990. “Culture Perspective on Changing and Developing Organizational Ethics" in Research in Organizational Change and Development, 4 (1990), p. 195-230.

- Van der Post, W.Z., De Koning, T.J., \& Smit, E.M. 1998. The relationship between organizational culture and financial performance: some South African evidence. South African Journal of Business Management, 29(1), 30-40. 
- Webster, F.E. Jr. 1993. Corporate culture, customer orientation, and innovativeness in Japanese firms: a quadrant analysis. The Journal of Marketing, 57(1), 23-37.

- Weiss, K.E. 1986. “Minerva's Owl, Building a Corporate Value System” in Journal of Business Ethics 5(1986),p.243-247.

- Willcoxson, L. \& Millett, B. 2000. The management of organizational culture. Australian Journal of Management \& Organizational Behaviour, 3(2), 91-99.

- Yoon, S.J., Choi, D.C., \& Park, J.W. 2007. Service Orientation: its impact on business performance in the Medical Service Industry. The Service Industries Journal, 27(4), 371-388.

\section{AUTHOR'S CONTACT}

\section{SEBEDI, $K$.}

South African Revenue Service

Email: ksebedi@sars.gov.za 